ep=rep1\&type=pdf [in English].

Gołębiowska, A. (2016). Poszanowanie prawa do wolności i bezpieczeństwa osobistego w Konstytucji Rp oraz w aktach prawa międzynarodowego. Ogólnopolska konferencja naukowa «Wyzwania bezpieczeństwa cywilnego». URL: http://press.warszawa.pl/konferencja-wyzwaniabezpieczenstwa-cywilnego [in Polish].

Koziej, S. (2011). Bezpieczeństwo: istota, podstawowe kategorie i historyczna ewolucja. Bezpieczeństwo narodowe. 18. 19-39 [in Polish].

УДК 37.013.83:331.36

DOI: https://doi.org/10.35387/od.1(17).2020.89-97

Тарасова Олена Володимирівна - кандидат психологічних наук, доцент, доцент кафредри інженерної педагогіки та мовної підготовки Криворізького національного університету

ORCID iD: https://orcid.org/0000-0002-0756-4947

E-mail: tarasova.olenav@knu.edu.ua

Сулима Тетяна Сергіївна - кандидат педагогічних наук, доцент, доцент кафедри інженерної педагогіки та мовної підготовки Криворізького національного університету

ORCID iD: https://orcid.org/0000-0002-8869-040X

E-mail: sulyma@knu.edu.ua

\title{
РОЗВИТОК ПСИХОЛОГО-ПЕДАГОГІЧНОЇ КОМПЕТЕНТНОСТІ ВИКЛАДАЧІВ ТЕОРЕТИЧНОГО НАВЧАННЯ ТА ІНСТРУКТОРІВ ВИРОБНИЧОГО НАВЧАННЯ В УМОВАХ ПРОМИСЛОВОГО ПІДПРИЄМСТВА: АНДРАГОГІЧНИЙ АСПЕКТ
}

\begin{abstract}
Анотація. В оглядовій статті порушено проблему розвитку психолого-педагогічної компетентності викладачів теоретичного навчання та інструкторів виробничого навчання в умовах промислового підприємства з урахуванням андрагогічних засад. Адже в сучасних умовах підготовка, перепідготовка та підвищення кваліфрікації працівників на виробництві вимагає самонавчання, швидкої та успішної зміни діяльності або умов праці, безперервного фрормального та неформального навчання. Оскільки прояв профресійної компетентності неможливий без належного рівня кваліфікації працівників, акцентовано увагу на понятті «якість профресійного навчання на виробництві». Здійснено науковометодичний аналіз проблеми застосування андрагогічного підходу до професійного навчання в умовах виробництва. Обгрунтовано, що задля ефективного удосконалення психолого-педагогічної компетентності викладачів профресійного навчання на виробництві доцільним $\epsilon$ проведення курсу «Психолого-педагогічний мінімум». Акцентовано увагу на використанні технології комбінованого навчання, згідно з якою слухачі активно можуть співпрацювати з викладачами як в аудиторії, так $i$
\end{abstract}


дистанційно за допомогою системи Moodle. Підкреслено, що застосування андрагогічних принципів у професійному навчанні в умовах промислового підприємства створює можливості для реалізації важливого на сьогодні суб'єктно-діяльнісного навчання, яке дозволяє дорослому учню відчувати себе суб'єктом, для якого забезпечено культурне й духовне зростання, а також розвиток як майбутніх творчих фрахівців у навчально-виробничому процесі на виробництві.

Ключові слова: андрагогічний підхід; профресійне навчання в умовах промислового підприємства; психолого-педагогічна компетентність; андрагогічні принципи навчання.

Tarasova Olena - Candidate of Psychological Sciences, Associate Professor, Assistant Professor of Engineering Pedagogy and Language Training Department of Kryvyi Rih National University

ORCID iD https://orcid.org/0000-0002-0756-4947

E-mail: tarasova.olenav@knu.edu.ua

Sulyma Tetyana - Candidate of Pedagogical Sciences, Associate Professor, Assistant Professor of Engineering Pedagogy and Language Training Department of Kryvyi Rih National university

ORCID iD: https://orcid.org/0000-0002-8869-040X

E-mail: sulyma@knu.edu.ua

\title{
DEVELOPMENT OF PSYCHOLOGICAL AND PEDAGOGICAL COMPETENCE OF THEORETICAL TRAINING TEACHERS AND INSTRUCTORS OF INDUSTRIAL TRAINING IN THE CONDITIONS OF INDUSTRIAL ENTERPRISE: ANDROGOGICAL ASPECT
}

\begin{abstract}
The issue of psychological and pedagogical competence development of theoretical training teachers and instructors of industrial training in the conditions of the industrial enterprise taking into account andragogical bases is considered in the article. So, in modern conditions of training, retraining and advanced training of workers in production requires self-study, rapid and successful change of activities or working conditions, continuous formal and informal training. Since the manifestation of professional competence is impossible without the appropriate level of workers' qualification, we focus on the concept of "quality of professional training in the workplace». The scientific and methodical analysis of the andragogical approach implementation problem to professional training in the conditions of production is carried out. It is reasoned that in order to improve the psychological and pedagogical competence of vocational training teachers in the workplace effectively it is advisable to conduct a course «Psychological and pedagogical minimum». The use of blended learning technology is emphasized according to which students can actively collaborate with teachers both in the classroom and remotely using the Moodle system. It is stated that the application of andragogical principles in vocational training in the conditions of industrial
\end{abstract}


enterprise creates opportunities for the implementation of today's important subject-activity learning which allows an adult student to feel like a subject for which cultural and spiritual growth and future creative specialists development in the training and industrial process in production are provided.

Key words: andragogical approach; professional training in the conditions of the industrial enterprise; psychological and pedagogical competence; andragogical principles of learning.

Постановка проблеми, її актуальність. Питання ефективної організації професійної діяльності працівників набуває високої актуальності в сучасних умовах соціально-економічного розвитку промисловості України. Науково-технічний прогрес у нашій країні ставить високі вимоги до кваліфрікації робітника, до його професійної майстерності. Від того наскільки рівень професійної підготовки працівників відповідає потребам розвитку економіки, значною мірою залежать темпи зростання продуктивності праці, обсягів виробництва і валовий внутрішній продукт України, рівень зайнятості населення.

Сучасний фахівець для успішної професійної діяльності в новому інфрормаційному суспільстві повинен бути здатний продуктивно та творчо розв'язувати завдання й проблеми, використовувати сучасні технології при розробці нових зразків техніки, виявляти здібності до творчого профресійного саморозвитку. Водночас, досягнення вершин у кар'єрі фрахівця неможливо без його потреби у поєднанні праці із саморозвитком, самоосвітою і самовдосконаленням. Незаперечним $€$ те, що наявність потреби в освіті на особистісному рівні передбачає збагачення особистості новими знаннями, визначає професійне й особистісне зростання, уможливлює соціалізацію, самореалізацію, а також формує спосіб життя.

На думку Л. Лук'янової, характер освітніх потреб відіграє значну роль у процесі самоствердження людини, забезпечує процес пізнання, сприяє мобілізації волі, визначає вектор цільових настанов, формує низку соціально важливих якостей особистості (Лук'янова, 2018, с. 52). Саме тому в сучасних умовах підготовка, перепідготовка та підвищення кваліфікації на виробництві вимагає фрормування не лише тих умінь, що потрібні безпосередньо для професійної діяльності, але й навичок ефективного самонавчання, швидкої та успішної зміни діяльності або умов праці, безперервного підвищення кваліфікації в умовах формального та неформального навчання. Необхідність формування професійної мобільності кваліфікованих працівників визначає нові вимоги до цілей виробничого та професійного навчання:

- формування навичок самостійного пошуку, отримання, добору та опрацювання навчальних відомостей;

- розвиток навичок використання сучасних ІКТ у навчанні та спільній діяльності;

- формування навичок використання отриманих знань та умінь у суміжних галузях виробництва.

Bce це вимагає систематичного підвищення професійно- 
кваліфікаційного рівня працівників, який, у свою чергу, досягається в процесі професійного навчання кадрів на виробництві з урахуванням тенденцій розвитку освіти дорослих.

Аналіз останніх досліджень і публікацій. У сучасній педагогічній науці досліджуються різні аспекти професійного навчання на виробництві - від теоретико-методологічних засад (Н. Ничкало, В. Радкевич), тенденцій розвитку професійного навчання на виробництві (Л.Герганов, А. Михайличенко, М. Михнюк, А. Селецький), нормативно-правового забезпечення та економічнічних аспектів (В. Савченко) до проблеми формування професійної компетентності кваліфікованих робітників (В. Аніщенко, В. Свистун). Не менш значна увага науковців приділяється також андрагогічним засадам організації професійного навчання дорослих (Л. Лук'янова, О. Аніщенко, О. Баніт, О. Коваленко, Т. Калюжна, Т. Котирло, В. Піддячий).

Так, Л. Лук'янова наголошує, що призначення сфери освіти дорослих у широкому значення полягає у забезпеченні доступу до освіти, відкритості освіти як у горизонтальній, так і вертикальній площинах, якості освіти, що гарантує конкурентоспроможність й мобільність дорослих (Лук'янова, 2019, с. 162). Для цього в системі професійного навчання на виробництві слід створювати сприятливі умови.

Серед тих умов, що впливають на якість професійного навчання виробничого персоналу, Н. Ничкало та В. Радкевич визначають наявність на підприємствах кваліфікованих штатних викладачів-педагогів (Ничкало, 2011; В. Радкевич, 2011). Такої ж думки дотримується і В. Свистун, яка вважає, що однією з умов, від якої в значній мірі залежить якість профресійного навчання на виробництві, $€$ належний рівень кваліфікації працівників, які організовують і здійснюють цю діяльність (Свистун, 2012, с. 6). Як показує практика, основні недоліки в діяльності підприємств щодо профресійного навчання кадрів на виробництві $€$ наслідком незнання відповідними працівниками вимог нормативно-правових документів, відсутність у працівників, які проводять заняття з професійно-теоретичного та професійно-практичного навчання, базової педагогічної освіти, а відповідно й психолого-педагогічної компетентності.

Мета статті - здійснити науково-методичний аналіз та запропонувати шляхи вирішення проблеми застосування андрагогічних підходів до професійного навчання в умовах промислового підприємства.

Виклад основного матеріалу дослідження. Згідно 3 Положенням про професійне навчання кадрів на виробництві, а також Положенням про організацію навчально-виробничого процесу на виробництві, працівники, які здійснюють професійне навчання робітників на виробництві та не мають педагогічної освіти, повинні пройти навчання 3 основ психології, виробничої педагогіки, особливостей навчання дорослих. Це зумовлено тим, як зазначає В. Свистун, що сучасні динамічні процеси суспільно-економічного життя в державі (глобалізація, інформатизація, демократизація, гуманізація, технологізація тощо) потребують суттєвого оновлення змісту, методів, методик, технологій та організаційних форм 
підготовки майбутніх кваліфікованих робітників в умовах виробництва (Свистун, 2012, с. 5).

У Східному регіоні України в умовах масового відтоку робітничих кадрів за кордон промислові підприємства потребують висококваліфрікованих фрахівців з гірництва, машинобудування, металургії, електромеханіки, автоматизації систем керування тощо. Водночас, досвід співпраці Криворізького національного університету 3 такими підприємствами, демонструє, що забезпечити якісне професійне навчання робітників в умовах виробництва не завжди вдається. Інженерно-технічним фрахівцям, які організовують і здійснюють теоретичну та практичну підготовку робітників, підвищують їх кваліфрікацію, недостатньо високого професіоналізму, у них повинна бути сформована й психолого-педагогічна компетентність.

3 метою формування та удосконалення психолого-педагогічної компетентності викладачів професійного навчання кадрів на виробництві 3 2012 року провідні викладачі кафедри інженерної педагогіки та мовної підготовки Криворізького національного університету проводять курси підвищення кваліфікації працівників, які залучаються до організації та проведення професійного навчання на базах підприємств м. Кривого Рогу та за його межами: ПАТ «АрселорМіттал Кривий Ріг» (м. Кривий Ріг), ПрАТ «Центральний гірничо-збагачувальний комбінат» (м. Кривий Ріг), ПрАТ «Полтавський ГЗК» (м. Горішні плавні), ПрАТ «Євраз - Дніпровський металургійний завод ім. Петровського» (м. Дніпро), ПрАТ «СЕНTPABIC ПРОДАКШН ЮКРЕЙН» (м. НікОпОЛЬ), ТОВ «МЕТІНВЕСТ-КРМЗ» (м. КривиЙ Ріг), ПАТ «Дніпроазот» (м. Кам'янське), ПАТ «Кривбасзалізрудком» (м. Кривий Ріг), ПАТ «ХайдельбергЦемент Україна» (м. Кривий Ріг), TOB «Промремонти» (м. Кривий Ріг), ДП «Східний гірничо-збагачувальний комбінат» (м. Кривий Ріг), ПАТ «Дніпропетровськгаз» (м. Дніпро), ПрАТ «Енергоресурси» (м. Нікополь), ПрАТ «Нікопольський завод технологічного оснащення» (м. Нікополь), ПАТ «Нікопольський завод фреросплавів» (м. Нікополь), ДП «Східний гірничо-збагачувальний комбінат» (м. Жовті Води), ПАТ «Новомосковський трубний завод (м. Новомосковськ) та ін. Проєкт отримав назву «Психолого-педагогічний мінімум». Основними його завданнями $є$ :

- вивчення когнітивних процесів, психологічних механізмів та проявів емоцій і почуттів людини, структури та особливостей ії вольових якостей;

- визначення індивідуальних особливостей особистості та розробці на цій основі індивідуальних стратегій і програм саморозвитку;

- набуття практичних навичок у розв'язанні конфліктів, умінь контролювати конфліктну ситуацію;

- засвоєння сучасних психотехнологій управління персоналом і формування навичок ефективного керівництва;

- вивчення основ професійної педагогіки, андрагогіки, принципів, закономірностей, прийомів, методів, засобів та форм організації професійного навчання дорослих; 
- ознайомлення фрахівців 3 механізмом трансформування технічного знання в педагогічну систему професійного навчання дорослих та методику дидактичного проектування на рівні професії, навчального курсу та теми;

- набуття практичних навичок аналізу та конструювання змісту професійного навчання, розробки навчальних матеріалів (за профілем підготовки).

Слухачі мають засвоїти два блоки змістових модулів, представлених у табл. 1.

Таблиця 1

Структура психолого-педагогічного мінімуму

\begin{tabular}{|c|c|}
\hline $\begin{array}{c}\text { Назва блоків } \\
\text { змістових } \\
\text { модулів }\end{array}$ & Зміст змістових модулів \\
\hline $\begin{array}{c}\text { Модуль №1. } \\
\text { Психологічний } \\
\text { мінімум }\end{array}$ & $\begin{array}{l}\text { Психологічна структура особистості. Психічні процеси } \\
\text { та властивості особистості. Психологія професійної } \\
\text { діяльності. Творча діяльність. Психологічні аспекти } \\
\text { управлінської діяльності. Емоційна сфера особистості. } \\
\text { Психічне та духовне здоров'я керівника. Спілкування як } \\
\text { соціально-психологічна проблема. Ефективне ділове } \\
\text { спілкування. Психологія ефективного керівника-лідера. } \\
\text { Імідж керівника. Конфлікти в діловому спілкуванні. } \\
\text { Ефективні стратегії управління конфліктами. }\end{array}$ \\
\hline $\begin{array}{c}\text { Модуль №2. } \\
\text { Педагогічний } \\
\text { мінімум }\end{array}$ & $\begin{array}{l}\text { Методологічні засади професійної педагогіки. } \\
\text { Андрагогічні принципи навчання. Методи професійного } \\
\text { навчання дорослих. Мотивація пізнавальної діяльності } \\
\text { дорослих. Форми організації професійного навчання } \\
\text { дорослих. Інноваційні педагогічні технології навчання } \\
\text { дорослих. Професійна компетентність викладача як } \\
\text { засіб фрормування висококваліфрікованого робітника. }\end{array}$ \\
\hline
\end{tabular}

Зазначений курс дає можливість слухачам, окрім підвищення рівня професійно-педагогічної компетентності, самореалізуватися як творчим особистостям; озброює їх теоретичними знаннями з сучасної психології й педагогіки, а також уміннями, що є необхідними для ефективної організації навчальної діяльності в умовах виробництва.

Аудиторне навчання, зважаючи на андрагогічний підхід, викладачі максимально урізноманітнюють міні-лекціями із застосуванням техніки зворотного зв'язку, тематичними лекціями з елементами евристичної бесіди, груповими дискусіями, ситуативними завданнями, психологопедагогічними тренінгами з використанням ділових ігор та кейс-технологій тощо. Така методика розвитку психолого-педагогічної компетентності викладачів професійного навчання кадрів на виробництві обов'язково реалізується з урахуванням принципу корегування застарілого досвіду та особистісних установок, що перешкоджають засвоєнню нових знань, а також принципу затребуваності результатів навчання практичною діяльністю дорослого слухача. 
Погоджуємося з думкою науковців, що з-поміж основних технологій навчання дорослих найбільш доцільними $€$ структурно-логічні (задані) технології навчання; комп'ютерні технології; тренінгові технології; дистанційні навчальні технології (Лук'янова, Аніщенко, Сігаєва, Зінченко, Баніт \& Дорошенко, 2013). Саме тому однією з особливостей курсу $є$ використання технології комбінованого навчання (blended learning), згідно 3 якою слухачі активно можуть співпрацювати з викладачами як в аудиторії, так і дистанційно за допомогою порталу «Віртуальний Криворізький національний університет». Як систему управління навчанням обрано найбільш поширену в Україні та світі систему Moodle. Простота інтерфейсу та гнучкість в управлінні роблять цю систему однією 3 найбільш привабливих для організації навчання працівників підприємства, які не мають спеціальної підготовки з використання інформаційних комп'ютерних технологій навчального призначення

Під час роботи з он-лайн курсом, розміщеним на цьому порталі, слухачі мають змогу знайомитися з основними теоретичними положеннями сучасної психологічної і педагогічної наук, пройти тестову перевірку знань, виконати творчі завдання. Така система роботи дозволяє реалізувати принцип пріоритетності самостійного навчання та принцип елективності у роботі з дорослими. Під час занять дорослі слухачі проявляють ініціативність, творчий підхід до розв'язання поставлених завдань, відкритість та небайдужість. Окрім того, слухачі беруть активну участь у дискусіях та отримують консультації викладачів.

Окрім навчального компонента, робота зі слухачами направлена на вдосконалення їх особистості, розвиток пізнавальних процесів, розвиток здібностей до самонавчання, формування професійно важливих якостей тощо. Значна увага з боку викладачів також приділяється дотриманню принципу реслексивності, оскільки свідоме ставлення дорослої людини до навчання має стати головною частиною самомотивації. Ті прийоми навчання, які застосовують викладачі курсу під час занять зі слухачами «Психолого-педагогічного мінімуму», можуть бути адаптовані до змісту їх професійних курсів та використані у роботі з учнями в умовах виробництва.

Зазначимо, що контроль успішності слухачів здійснюється за допомогою підсумкового заняття, яке передбачає використання комплексу нестандартних методів комплексного оцінювання їх теоретичних знань та практичних умінь (психолого-педагогічний кросворд, психолого-педагогічні ребуси, вікторина, конкурс на кращу методику удосконалення навчання робітників в умовах підприємства тощо).

Висновки і перспективи подальших досліджень. Професійне навчання в умовах промислового підприємства, що грунтується на засадах андрагогічного підходу, створює можливості для впровадження суб'єктнодіяльнісного навчання, яке на противагу авторитарному навчанню дозволяє дорослому учню відчувати себе суб'єктом освітньої взаємодії, для якого забезпечено культурне й духовне зростання та гармонійний розвиток як майбутніх творчих фахівців у навчально-виробничому процесі на виробництві. Зважаючи на актуальність порушеної проблеми та з метою 
забезпечення принципу затребуваності результатів навчання практичною діяльністю дорослого учня, вважаємо доцільним провести моніторинг освітніх потреб викладачів теоретичного навчання, майстрів виробничого навчання та наставників в умовах підприємств.

Перспективним напрямом подальших досліджень $€$ вивчення зарубіжного досвіду упровадження андрагогічного підходу у професійному навчанні фахівців в умовах промислових підприємств.

\section{Список використаних джерел}

Лук'янова, Л.Б. (2018). Освітні потреби різних категорій дорослих у контексті особистісного і професійного розвитку. Професійна освіта: адрагогічний підхід: монографія. Житомир: Вид. О.О. Євенок, 42-67.

Лук'янова, Л.Б. (2019). Тенденції розвитку освіти дорослих в Україні. URL: http://lib.iitta.gov.ua/718443/1/3.pdf.

Ничкало, Н. (2011). Проблеми професійного навчання на виробництві у контексті педагогіки, психології праці й андрагогіки. Профресійне навчання на виробництві: зб. наук. праць. К.: Вид-во Інституту професійно-технічної освіти НАПН України, 6-17.

Положення про організацію навчально-виробничого процесу на виробництві (2006, зі змінами 2017). URL: https://zakon.rada.gov.ua/laws/show/z003207.

Положення про професійне навчання кадрів на виробництві $(2001$, зі змінами 2018). URL: https://zakon.rada.gov.ua/laws/show/z0315-01.

Радкевич, В. (2011). Сучасні чинники розвитку професійного навчання в умовах виробництва. Професійне навчання на виробництві: зб. наук. праць; за ред. Радкевич В.О. К.: Вид-во Інституту професійно-технічної освіти НАПН України, 18-27.

Свистун, В.І. (2012). Педагогічні умови професійного навчання персоналу на виробництві. URL: http://lib.iitta.gov.ua/id/eprint/2719.

Лук'янова, Л.Б., Аніщенко, О.В., Сігаєва, Л.Є., Зінченко, С.В., Баніт, О.В., Дорошенко, Н.І. (2013). Сучасні технології освіти дорослих. Кіровоград: Імекс-лтД.

Вовк, М., Ходаківська, С. (2019). Технології навчання дорослих в умовах формальної і неформальної освіти. DOI: https://doi.org/10.35387/od.2(16).2019.39-48.

Dustmann, C., Schönberg, U. (2012). What makes firm-based vocational training schemes successful? The role of commitment. Am Econ J 4(2), 36-61.

\section{References (translated and transliterated)}

Lukianova, L. B. (2018). Osvitni potreby riznykh katehorii doroslykh u konteksti osobystisnoho i profesiinoho rozvytku [Educational needs of different adults' categories in the context of personal and professional development]. Profesijna osvita: adragogichnyj pidxid: monograph. Zhytomyr: Vyd. O.O. Yevenok, 42-67 [in Ukrainian].

Lukianova, L. B. (2019). Tendentsii rozvytku osvity doroslykh v Ukraini [Development trends of adult education in Ukraine]. URL: http://lib.iitta.gov.ua/718443/1/3.pdf [in Ukrainian].

Nychkalo, N. (2011). Problemy profesiinoho navchannia na vyrobnytstvi u konteksti 
pedahohiky, psykholohii pratsi y andrahohiky [Vocational training problems at production site in the context of pedagogy, work psychology and andragogy]. Profesijne navchannya na vyrobnycztvi: zb. nauk. prats. Kyiv: Vyd. Instytutu profesijno-texnichnoyi osvity NAPN Ukrayiny, 6-17 [in Ukrainian]

Polozhennia pro orhanizatsiiu navchalno-vyrobnychoho protsesu na vyrobnytstvi [Regulations on the organization of the training and production process in industries] (2006, as amended in 2017). URL: https://zakon.rada.gov.ua/laws/show/z0032-07 [in Ukrainian]

Polozhennia pro profesiine navchannia kadriv na vyrobnytstvi [Regulations on staff's professional training in industries] (2001, as amended in 2018). URL: https://zakon.rada.gov.ua/laws/show/z0315-01 [in Ukrainian]

Radkevych, V. (2011). Suchasni chynnyky rozvytku profesiinoho navchannia $v$ umovakh vyrobnytstva [Modern professional training development factors under the conditions of production.]. Profesijne navchannya na vyrobnycztvi: zb. nauk. prats. Kyiv: Vyd. Instytutu profesijno-texnichnoyi osvity NAPN Ukrayiny, 18-27 [in Ukrainian]

Svystun, V.I. (2012). Pedahohichni umovy profesiinoho navchannia personalu na vyrobnytstvi [Pedagogical conditions of staff's professional training in industries]. URL: http://lib.iitta.gov.ua/id/eprint/2719 [in Ukraine]

Lukyanova, L.B., Anishchenko, O.V., Sigaeva, L.E., Zinchenko, S.V., Banit, O.V., Doroshenko, N.I. (2013). Suchasni tekhnolohii osvity doroslykh [Modern technologies of adult education]. Kirovograd: Imex-LTD [in Ukrainian]

Vovk, M., Khodakivska, S. (2019). Tekhnolohii navchannia doroslykh $v$ umovakh formalnoi i neformalnoi osvity [Technologies of adult learning in formal and non-formal education]. DOI: https://doi.org/10.35387/od.2(16).2019.39-48 [in Ukraine]

Dustmann. C, Schönberg, U. (2012). What makes firm-based vocational training schemes successful? The role of commitment. Am Econ J 4(2): 36-61 [in English]

УДК 61:374.72

DOI: https://doi.org/10.35387/od.1(17).2020.97-105

Філатов Андрій Олександрович - аспірант Київського національного лінгвістичного університету

ORCID iD: https://orcid.org/0000-0002-1921-213X

E-mail: andriy.a.filatov@gmail.com

\section{ДО ПИТАННЯ ПРО НЕФОРМАЛЬНУ ОСВІТУ ФАХІВЦІВ У СФЕРІ ОХОРОНИ ЗДОРОВ'Я (НА ПРИКЛАДІ КОРПОРАТИВНОГО НАВЧАННЯ)}

Анотація. В оглядовій статті проаналізовано окремі аспекти проблеми неформальної корпоративної освіти фрахівців у галузі охорони здоров'я. Визначено необхідність впровадження корпоративної колаборації у сфреру підвищення кваліфікації лікарів і медичних працівників. Виокремлено завдання, що потребують вирішення: кваліфікована 